\title{
Circular Priorities in Secured Transactions LAW
}

\author{
RODERICK J. WOOD*
}

Circular priority problems are endemic in secured transaction law. A circular priority situation arises when there are three or more parties with competing claims to the same asset and there is no clear ranking of priority among them. There are multiple approaches applied by courts or advanced by commentators to resolve circular priority problems. The different mechanisms used by the courts to resolve a circular priority problem are evaluated using criteria that reflect the general values and goals of commercial law, and the mechanism that best accords with this criteria is identified. Although consensus on the best way of breaking a circularity will reduce litigation costs, it does not provide a complete solution, as it can be undermined by ex post bargaining among creditors. Given this instability, priority rules should be designed so as to limit the occasions when such problems can arise.
Les problèmes de priorité circulaire sont endémiques au droit des transactions garanties. Un problème de priorité circulaire survient lorsqu'il y a trois parties ou plus avec des revendications concurrentes pour le même actif et qu'il n'y a pas vraiment de hiérarchie claire entre eux. Il existe de nombreuses approches utilisées par les cours ou émises par des commentateurs dans le but de régler les problèmes de priorité circulaire. Les divers mécanismes que les cours utilisent pour régler ces problèmes sont évalués à la lumière de critères reflétant les valeurs générales et les objectifs du droit commercial; le mécanisme qui convient le mieux aux critères est identifié. Bien qu'un consensus sur le meilleur moyen de briser la circularité permette de réduire les frais de litige, il ne résout pas tout le problème parce qu'il peut être amoindri par des négociations « après coup » entre créanciers. Compte tenu de cette instabilité, des règles prioritaires devraient être élaborées afin de réduire au minimum les occasions où ces problèmes peuvent surgir.

\section{TABLE OF CONTENTS}

I. InTRODUCTION . . . . . . . . . . . . . . . . . . . . . . . . . 824

II. AN INVENTORY OF CIRCULAR PRIORITY SYSTEMS . . . . . . . . . . . . . 825

A. Case 1: Subordination AgreEment $\ldots \ldots \ldots \ldots \ldots \ldots . \ldots 26$

B. CASE 2: Buyer WITH KNOWLEDGE $\ldots \ldots \ldots \ldots \ldots \ldots \ldots \ldots . \ldots 26$

C. CASE 3: PuRchase-Money SeCURity

INTEREST IN INVENTORY $\ldots \ldots \ldots \ldots \ldots \ldots \ldots \ldots \ldots \ldots \ldots$

D. CASE 4: FiXtURES . . . . . . . . . . . . . . . . . . . . . . . 827

E. CASE 5: ACCESSIONS . . . . . . . . . . . . . . . . . . . . 827

F. CASE 6: LAPSE OR DisCHARGE Of A REgISTRATION ........ 828

G. CASE 7: CHANGE OF NAME OR TRANSFER OF INTEREST $\ldots \ldots \ldots 828$

H. CASE 8: FutURE ADVANCES AND JUdGMENT

ENFORCEMENT CREDITORS $\ldots \ldots \ldots \ldots \ldots \ldots \ldots \ldots \ldots . \ldots 28$

I. CASE 9: BANK ACT SECURITY . . . . . . . . . . . . . . . 829

J. Case 10: Statutory Deemed Trusts $\ldots \ldots \ldots \ldots \ldots . \ldots . \ldots 29$

III. The Resolution of APPARENT CirCUlar Priority Systems . . . . . 829

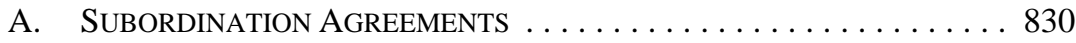

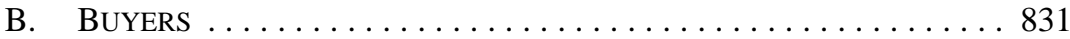

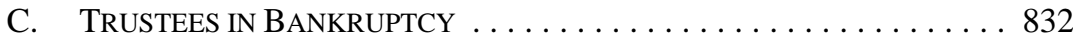

IV. The Resolution of TRUe CirCUlar Priority Systems $\ldots \ldots \ldots \ldots 835$

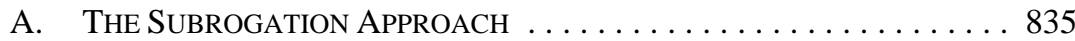

Professor, Faculty of Law, University of Alberta. I wish to thank Tamara Buckwold, Tony Duggan, and two anonymous expert referees for their helpful comments. 
B. The Fault Approach $\ldots \ldots \ldots \ldots \ldots \ldots \ldots \ldots \ldots \ldots \ldots$

C. The ReAsonable EXPECTATIONS APPROACH $\ldots \ldots \ldots \ldots \ldots . \ldots 837$

D. HYBRID APPROACHES . . . . . . . . . . . . . . . . . . . . . . . . 840

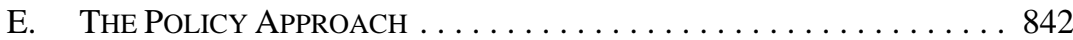

F. THE Conversion APPROACH $\ldots \ldots \ldots \ldots \ldots \ldots \ldots \ldots \ldots \ldots$

G. THE Residual Priority Rule APPROACH . . . . . . . . . . . . . . . . . 844

H. The Pro RATA APPROACH . . . . . . . . . . . . . . . . . . 844

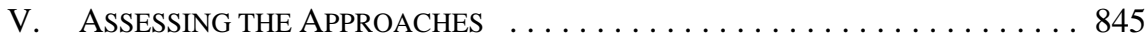

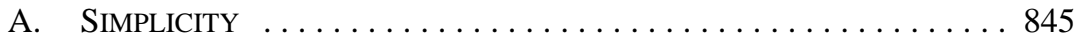

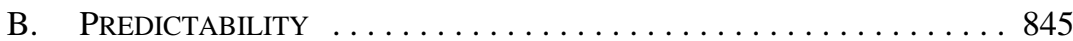

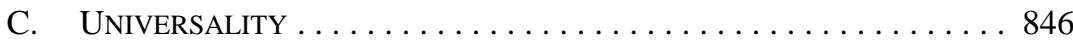

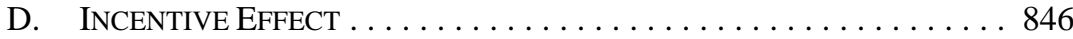

E. CONGRUENCE WITH COMMERCIAL EXPECTATIONS . . . . . . . . . . 847

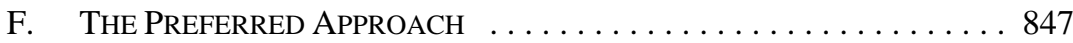

VI. The EfFect of EX Post BARgaining . . . . . . . . . . . . . . . . . . . . . 849

VII. Minimizing THE INCIDENCE OF CIRCULAR PRIORITY SYSTEMS . . . . . . 850

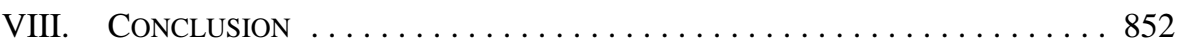

\section{INTRODUCTION}

Circular priority problems have vexed lawyers for a long time. ${ }^{1}$ Those who have endeavoured to resolve these problems claim that they can produce feelings of rage, ${ }^{2}$ embarrassment, ${ }^{3}$ and despair. ${ }^{4}$ No system of law governing secured transactions is immune from their deleterious influence. They arise in connection with both real property and personal property. The recent modernization and reform of secured transaction law has not produced any solution to the problem of the circulus inextricabilis. ${ }^{5}$ The difficulty arises from the very structure of priority rules. Priority rules typically take the form of a binary rule that gives one party priority over another. This works well so long as there are only two parties involved in the competition. A circular priority system may arise when there are three or more ${ }^{6}$ parties with competing claims to the same asset. The relevant priority rules are applied to rank each party's claim as against another of the competing claimants. It is

One of the earliest recorded cases is Ingram v. Pelham (1752), Amb. 153, 27 E.R. 102 (Ch. D.). For an early academic debate on the resolution of circular priority systems, see J. Randolph Tucker, "The Deeds of Trust Puzzle: A Legal Paradox” (1895) 1 Va. L. Reg. 4; John B. Moon, “'The Deeds of Trust Puzzle’ - A Reply” (1895) 1 Va. L. Reg. 254.

2 In an oft cited passage, Grant Gilmore, Security Interests in Personal Property (Boston: Little, Brown \& Co., 1965) vol. II at 1020-21 states that "[a] judge who finds himself face to face with a circular priority system typically reacts in the manner of a bull who has been goaded by the picadors: he paws the ground and roars with rage.”

3 Michael D. White, “Untangling Circular Priorities Under UCC Section 9-114” (1981) 86 Com. L.J. 231 at 233 claims that the existence of such problems is to be regarded as a "minor embarrassment" to the drafters of the statute.

$4 \quad$ In Andrus v. Burke, 48 A. 228 at 229 (N.J. Ct. Ch. 1901), Pitney V.C. stated that "I have never been able to understand the logic of this reasoning, having been taught while a law student that the legal puzzle presented by the situation was insoluble on any known principles.” See also Kingsberry Mortgage Co. v. Maddox, 233 N.E.2d 887 (Ohio Ct. Com. Pl., 1968) at 892 [Maddox] where it is stated: "[t]he court feels that there is no method of logic or mathematics then that can solve this problem."

5 This is the term used in E.H. Burn, ed., Cheshire and Burn's Modern Law of Real Property, 15 th ed. (London: Butterworths, 1994) at 722.

$6 \quad$ Eric Kades, “The Laws of Complexity and the Complexity of Laws: The Implications of Computational Complexity Theory for the Law" (1997) 49 Rutgers L. Rev. 403 at 457-60 demonstrates that the analysis can jump from merely complex to absolutely mind-boggling once more than three parties are involved in a multi-circuit circular priority system. 
possible that the cumulative result of this process is that no stable ranking of priority is produced. ${ }^{7}$ A has priority over B. B has priority over C. C has priority over A. If there are insufficient funds to satisfy all of their claims, some method must be found to break this circularity. ${ }^{8}$

I will begin, in Part II, by setting out ten cases that appear to create circular priority systems. By doing so, I hope to demonstrate that these problems are pervasive and cannot be dismissed as mere academic puzzles that are used by law professors to torture their students at exam time. In Part III, I will draw a fundamental distinction between apparent circular priority systems and true circular priority systems. The former can be easily resolved through the application of established legal principle — either through proper contractual interpretation or by application of the shelter principle of property law. The latter are not so easily resolved, and a search for some other method for breaking the circularity must be undertaken. In Part IV, I will canvass the various solutions or formulas that have been applied by the courts or proposed by legal commentators. The difficulty is not that there is no solution to circular priority systems, but that there are too many with little or no discussion of their relative advantages and disadvantages. In Part V, I will provide an assessment of these approaches by identifying a set of criteria that promote the general values and goals of commercial law, and I will use these criteria to test the various solutions that have been applied or proposed. Using this approach, I will identify an approach to the judicial resolution of circular priority problems that best fits the criteria. In Part VI, I will demonstrate that there is no "magic bullet" to the problem of circular priority systems. Even if courts agreed upon a formula to break a circular priority system, post-default bargaining among the parties can destroy the predictability of the judicial solution to the problem. In Part VII, I will conclude that the judicial response to the problem of circularity is at best a partial solution, and that the legislative design of priority rules and the proper coordination of commercial law statutes do much to minimize, but not eliminate, the incidence of circular priority systems.

\section{An InVEntory OF Circular Priority Systems}

A circular priority system is not an isolated or exceptional phenomenon. An inventory of circular priority systems is set out below in order to illustrate the wide variety of circumstances in which they can be generated. Although this covers many of the circular priority systems that are likely to arise, it is not intended to be an exhaustive list of all possibilities. Furthermore, the list has been restricted to those circular priority systems that arise in connection with secured transactions in personal property. Although circular priority to rights," a circular priority system "prohibits logical priority.” For this reason, he refers to a circularity as "the antithesis of priority." 
problems also arise in respect of real property ${ }^{9}$ and many of the proposed solutions were first developed in this context, the list has been restricted simply to place a limit on an already lengthy inventory.

\section{A. Case 1: Subordination Agreement}

SP1 (secured party) registers first. SP2 registers second. SP3 registers third. SP1 agrees to subordinate its claim in favour of SP3. SP1 has priority over SP2 by virtue of SP1's earlier registration. ${ }^{10}$ SP2 has priority over SP3 by virtue of SP2's earlier registration. SP3 has priority over SP1 by virtue of the subordination agreement. ${ }^{11}$

\section{B. CASE 2: BUYER WITH KNOWLEDGE}

SP1 registers first. SP2 registers second. B (buyer) buys goods from the debtor in the ordinary course of business of the debtor. B knows that the sale constituted a breach of SP2's security agreement, but did not know of SP1's security interest. SP1 has priority over SP2 by virtue of SP1's earlier registration. SP2 has priority over B. B cannot assert the ordinary course buyer rule against SP2, since B knew that the transaction violated the terms of SP2's security agreement. ${ }^{12} \mathrm{~B}$ takes free of SP1's security interest because B can invoke the ordinary course buyer rule.

There are several other priority rules that afford protection to a buyer if the buyer does not know of a prior security interest. Some of these apply to goods, ${ }^{13}$ but some apply to other categories of collateral, such as instruments and documents of title. ${ }^{14}$ Each of these rules can give rise to a similar problem when a buyer has knowledge of a junior security interest but not of a senior security interest.

\section{CASE 3: Purchase-Money Security InTEREST In INVENTORY}

SP1 takes a security interest in all present and after-acquired personal property and registers first. SP2 takes a security interest in all present and after-acquired personal property and registers second. PMSP (purchase-money secured party) takes a purchase-money security interest in the inventory that it supplies to the debtor. PMSP registers third in time, and gives notice of its intention to take a purchase-money security interest to SP1, but not to SP2. SP1 has priority over SP2 by virtue of SP1's earlier registration. ${ }^{15}$ SP2 has priority over PMSP, since PMSP's failure to notify SP2 means that priority will be determined by the

A single example must suffice for now. A takes a mortgage on land but fails to register. B registers a judgment or writ in the land registration system. C takes a second mortgage and registers it. A has priority over B (since the lack of registration does not alter the rule that the writ only binds the debtor's interest in the land). $\mathrm{B}$ has priority over $\mathrm{C}$, because $\mathrm{C}$ takes the mortgage subject to the binding effect of B's writ. C has priority over A because of A's failure to register. R.S.O. 1990, c. P.10, s. 30(1) [OPPSA]. The Alberta Act will be used as representative of the common law jurisdictions, other than Ontario, that use a substantially similar model. Unless otherwise indicated, a reference to the "PPSA" refers to both models of legislation.

APPSA, ibid., s. 40; OPPSA, ibid., s. 38.

APPSA, ibid., s. 30(2); OPPSA, ibid., s. 28(1).

See APPSA, ibid., ss. 30(3)-(8); OPPSA, ibid., s. 28(5).

See APPSA, ibid., s. 31; OPPSA, ibid., ss. 28(3), (4), (6).

APPSA, ibid., s. 35(1); OPPSA, ibid., s. 30(1). 
order of registration. PMSP has priority over SP1, since PMSP has satisfied the conditions necessary to invoke its purchase-money security interest superpriority. ${ }^{16}$

\section{CASE 4: FiXTURES}

There are two scenarios that can give rise to circular priority systems in respect of fixtures. In the first scenario, M1 (mortgagee) is granted a real property mortgage in the debtor's land. SP takes a security interest in goods. SP fails to file a fixtures notice in the land registration system. The goods are then affixed to the land. The debtor grants a second real property mortgage to M2. M1 has priority over M2 by virtue of its earlier registration in the land registration system. M2 has priority over SP because SP's failure to register a fixtures notice renders its interest subordinate to parties who subsequently acquire interests in the land. ${ }^{17} \mathrm{SP}$ has priority over M1 since the failure to file the fixtures notice does not affect its priority over a pre-existing real property interest. ${ }^{18}$ An express priority rule that is designed to resolve this circularity has been included in the personal property security legislation of Saskatchewan and the Atlantic provinces. ${ }^{19}$

In the second scenario, SP1 takes a security interest in goods and registers only in the personal property registry. SP2 takes a security interest in the same goods, registers in the personal property registry, and files a fixture notice in the land registration system. The goods are then affixed to the land. $\mathrm{M}$ is then given a real property mortgage in the land. SP1 has priority over SP2 because of its earlier registration. SP2 has priority over M since it protected its interest by filing a fixtures notice. M has priority over SP1 because of SP1's failure to file a fixtures notice.

\section{E. CASE 5: ACCESSIONS}

SP1 has a security interest in the dominant goods, while SP2 has a security interest in the accession goods. SP2 does not register or otherwise perfect its security interest. The accession goods are then installed or affixed to the dominant goods. SP3 subsequently takes a security interest in the whole and registers its security interest. SP2 has priority over SP1 since SP2 has a right to remove the accessions, and the failure to perfect its security interest only subordinates its right in respect of subsequent transferees. ${ }^{20}$ SP3 has priority over SP2 because SP3 acquired its interest after the goods became an accession. ${ }^{21}$ SP1 has priority over

APPSA, ibid., s. 34(3); OPPSA, ibid., s. 33(1)(b).

APPSA, ibid., s. 36(3); OPPSA, ibid., s. 34(2).

APPSA, ibid., s. 36(2); OPPSA, ibid., s. 34(1)(a).

The PPSA in those provinces contain an additional subsection in the fixtures provisions that states that the priority conferred upon a subsequent real property interest holder is not affected by priority rights to the land provided under provincial land registration law: see e.g. Personal Property Security Act, 1993, S.S. 1993, c. P-6.2, s. 36(18). Law Reform Commission of Saskatchewan, Proposals for a New Personal Property Security Act (Saskatoon: Law Reform Commission of Saskatchewan, 1992) at 57-58 indicates that this was intended to break the circularity by first resolving the priority competition between SP and M2. This gives priority to M2. The competition between M1 and M2 in respect of the land, including the fixtures, is then resolved by applying the usual priority rules of the land registration system. M1 therefore has the higher-ranking claim followed by M2.

APPSA, supra note 10, s. 38(2); OPPSA, supra note 10, s. 35(1)(a).

APPSA, ibid., s. 38(3); OPPSA, ibid., s. 35(2). The Ontario provision only gives priority to a subsequent buyer or a secured party who has a prior perfected security interest who makes a subsequent advance. It therefore does not seem to apply to a secured party who acquires its security interest after the goods are affixed. This is thought to be the result of a drafting error and some experts have proposed a "creative" interpretation that would nevertheless give priority to a subsequent secured party: see Jacob 
SP3 since the accession goods have become part of the whole, and SP1 has the earlier registration.

\section{F. CASE 6: LAPSE OR DISCHARgE OF A REgISTRATION}

SP1 registers first. SP2 registers second. SP1's registration lapses or is discharged. SP3 registers. SP1 re-registers. SP1 has priority over SP2 since the re-registration is effective to preserve SP1's priority over SP2. ${ }^{22}$ SP2 has priority over SP3 by virtue of SP2's earlier registration. SP3 has priority over SP1. SP1 can no longer assert that it has the earlier registration due to the lapse or discharge of its registration. The re-registration does not give SP1's security interest priority over a security interest that arose after the lapse or discharge of SP1's registration and before re-registration.

\section{G. CASE 7: CHANGE OF NAME OR TRANSFER OF INTEREST}

SP1 registers first. SP2 registers second. There is a change in the debtor's name or a transfer of the debtor's interest to another party. SP2 registers a financing change statement that discloses the new name within the appropriate time period after learning of the new name or transfer. SP1 fails to follow suit. SP3 registers using the new debtor name. SP1 has priority over SP2, by virtue of its earlier registration. SP2 has priority over SP3 since the amendment of its registration within the prescribed time period prevents its subordination. SP3 has priority over SP1 since SP1 failed to amend and SP3 (but not SP2) falls within the class of persons who are given priority. ${ }^{23}$ This type of circular priority system does not arise in Ontario, because a failure to amend results in a loss of perfection. ${ }^{24}$ Therefore, SP1's security interest is subordinate to both SP2 and SP3 in Ontario.

\section{H. CASE 8: Future AdVANCES AND JUdgment ENFORCEMENT CREDITORS}

SP1 and SP2 both take security interests that secure future advances. SP1 registers first, SP2 second. J (judgment enforcement creditor) obtains judgment and invokes the steps that would afford the claim priority over an unperfected security interest. ${ }^{25}$ SP1 learns of J's claim, but SP2 does not. Both SP1 and SP2 make future advances to the debtor. SP1 has priority over SP2 because of SP1's earlier registration. SP2 has priority over J since SP2 did not know of J's claim at the time it made the future advance. ${ }^{26} \mathrm{~J}$ has priority over SP1 in respect of SP1's future advance because SP1 knew of J's claim at the time of its future

S. Ziegel \& David L. Denomme, The Ontario Personal Property Security Act: Commentary and Analysis, 2d ed. (Toronto: Butterworths, 2000) at 309-10.

22 In all provinces except Ontario, the PPSA provides that SP1 must re-register within 30 days of the lapse or discharge in order for SP1 to preserve its priority over SP2: see e.g. APPSA, ibid., s. 35(8). In Ontario, there is no time limit for re-registration: see OPPSA, ibid., s. 30(6).

APPSA, ibid., ss. 51(2)-(3).

OPPSA, supra note 10 , s. 48.

In some jurisdictions, this involves registration of the claim in the personal property registry. In others, it requires that the judgment enforcement creditor cause the property to be seized under legal process. See Ronald C.C. Cuming, Catherine Walsh \& Roderick J. Wood, Personal Property Security Law (Toronto: Irwin Law, 2005) at 395-404.

26 APPSA, supra note 10, s. 35(6); OPPSA, supra note 10, s. 30(4). The OPPSA provision requires that the secured party receive written notification, whereas the $A P P S A$ provision merely requires that the secured party have knowledge of the interest. 
advance. ${ }^{27}$ The circular priority is restricted to the amount of SP1's new advances since both SP1 and SP2 maintain priority over $\mathrm{J}$ in respect of earlier extensions of credit.

\section{CASE 9: BANK ACT SECURITY}

SP1 takes a security interest and registers in the personal property registry. BK (bank) takes a Bank $A c t^{28}$ security and registers in the BA registry. SP2 takes and registers a purchase-money security interest in a new farm implement to secure a loan that it makes to permit the debtor to acquire the implement. SP1 has priority over BK in respect of the farm implement, since SP1's security interest arose before BK's security came into existence. ${ }^{29}$ BK has priority over SP2 by virtue of the fact that BK's security interest arose before SP2's came into existence. ${ }^{30} \mathrm{SP} 2$ has priority over SP1, since SP2 may invoke its purchase-money security interest superpriority over SP1. ${ }^{31}$

\section{J. CASE 10: StatuTORY DeEMEd TRUSTS}

SP1 registers first. SP2 reserves title to the goods it sells to the debtor to secure the unpaid purchase price, but SP2 fails to register in time to permit it to invoke its purchase-money security interest superpriority over SP1. A statutory deemed trust arises in favour of the Crown (C) in connection with unremitted source deductions. ${ }^{32}$ SP1 has priority over SP2, since SP1 has the earlier registration, and SP2 is unable to invoke its superpriority due to its failure to register within the appropriate time period. SP2 has priority over C because it has retained title to the goods, and the priority provisions in the federal statute do not give the deemed trust priority over this type of interest. ${ }^{33} \mathrm{C}$ has priority over SP1 since the federal priority rule applies and gives the deemed trust priority over earlier security interests.

\section{The Resolution Of APPARENT Circular Priority Systems}

The first two cases listed above do not create true circular priority systems. ${ }^{34}$ As well, circular priority systems in which one of the competing claimants is a trustee in bankruptcy

Ibid.

Bank Act, S.C. 1991, c. 46, ss. 427-29 [BA]; see generally, Ronald C.C. Cuming \& Roderick J. Wood, "Compatibility of Federal and Provincial Personal Property Security Law” (1986) 65 Can. Bar Rev. 267; Jacob S. Ziegel, "Interaction of Personal Property Security Legislation and Security Interests under the Bank Act” (1986) 12 Can. Bus. L.J. 73; Jacob S. Ziegel, “The Interaction of Section 178 Security Interests and Provincial PPSA Security Interests: Once More into the Black Hole” (1991) 6 B.F.L.R. 343; Ronald C.C. Cuming, "PPSA — Section 178 Bank Act Overlap: No Closer to Solutions” (1991) 18 Can. Bus. L.J. 135; Roderick J. Wood, "The Nature and Definition of Federal Security Interests" (2001) 34 Can. Bus. L.J. 65; Marc-Alexandre Poirier, “Analysis of the Interaction between Security under Section 427 of the Bank Act and Provincial Law: A Bijural Perspective” (2003), 63 R. du B. 287. Bank of Montreal v. Pulsar Ventures Inc. (1987), [1988] 1 W.W.R. 250 (Sask. C.A.) [Pulsar]; see also Innovation Credit Union v. Bank of Montreal, 2009 SKCA 35, [2009] 8 W.W.R. 473 at para. 2.

Royal Bank v. Moosomin Credit Union, 2003 SKCA 115, [2004] 5 W.W.R. 494. A purchase-money security interest has priority over a prior Bank Act security only if it is in the form of a title retention device reserved by a seller: see Kawai Canada Music Ltd. v. Encore Music Ltd. (1993), 10 Alta. L.R. (3d) 105 (C.A.) [Kawai]; YMCF Inc. v. 406248 B.C. Ltd. (1998), 52 B.C.L.R. (3d) 359 (S.C.) [YMCF]. APPSA, supra note 10, s. 34(2); OPPSA, supra note 10, s. 33(2).

Income Tax Act, R.S.C. 1985 (5th Supp.), c. 1, s. 227(4.1).

DaimlerChrysler Financial Services (debis) Canada Inc. v. Mega Pets Ltd., 2002 BCCA 242, 212 D.L.R. (4th) 41; Canada (Deputy Attorney General) v. Schwab Construction Ltd., 2002 SKCA 6, [2002] 4 W.W.R. 628; see also Jacob S. Ziegel, "Conditional Sales and Superpriority Crown Claims Under ITA s. 227” (2003) 38 C.B.R. (4th) 161.

$34 \quad$ Case 1: Subordination Agreement; Case 2: Buyer with Knowledge. 
do not generally create true circular priority problems. Although these cases at first appear to fit the pattern of a circular priority system, there is a principled means through which the apparent circularity can be broken and the priorities resolved.

\section{A. Subordination Agreements}

Case 1, described above, appears to create a circular priority system. It arises when a firstranking secured party subordinates its claim to a third-ranking secured party, but not to a second-ranking secured party. However, this does not give rise to a true circular priority problem. There is no circularity in the priority rules that determine the priorities of the respective claimants. The PPSA priority rules confer priority in the order of registration: (1) SP1; (2) SP2; (3) SP3. The subordination of SP1's claim in favour of SP3 does not operate in the same manner as a priority rule that gives SP3 priority over SP1. Rather, SP1 has simply agreed to surrender the benefit of its first-ranking security interest. The subordination agreement is a merely a private contract between the parties.

The real controversy concerns the proper interpretation of the subordination agreement. In the United States, the issue is framed as whether SP1 intended a complete subordination of its claim or only a partial subordination. ${ }^{35}$ A complete subordination occurs if the subordination agreement is interpreted as an agreement by SP1 not to assert its claim against the collateral until SP3's claim is satisfied. It does not involve an agreement by SP1 to turn over the benefit of its priority to SP3. Rather, it is essentially an agreement by SP1 to step aside and not assert its claim until SP3's claim has been satisfied. On this view, the competition is resolved by giving first priority to SP2, second priority to SP3, and third priority to SP1. SP2 is the indirect beneficiary of the subordination agreement because SP3 cannot satisfy its claim until the claim of SP2 is fully satisfied. ${ }^{36}$

Under the competing partial subordination theory, a subordination agreement is interpreted as an agreement under which SP1 agrees to turn over the benefit of its priority to SP3. The priorities are therefore resolved in the following manner. ${ }^{37}$ First, the amount of SP1's claim is set aside out of the fund. Second, the amount set aside is used to satisfy SP3's claim. If there is anything left over, it is paid to SP1. Third, SP2's claim is satisfied out of the remaining balance in the fund. Fourth, any excess is distributed to SP3, and then to SP1.

Under a partial subordination theory, SP2 neither benefits nor is prejudiced by the subordination agreement between SP1 and SP3. The only effect of the subordination agreement is to give SP3 the money that would otherwise have been paid to SP1. This accords with their intentions. SP1 intended to subordinate its claim to SP3, but had no intention to do so in respect of SP2. Thus, amounts obtained by SP1 must be turned over to SP3, and any amounts left over after SP2's claim is satisfied must also be used to satisfy SP3's claim. ${ }^{38}$ This approach has also been referred to as a subrogation approach, since the

35 See George A. Nation III, "Circuity of Liens Arising From Subordination Agreements: Comforting Unanimity No More” (2003) 83 B.U.L. Rev. 591.

See AmSouth Bank, N.A. v. J\&D Financial Corp., 679 So.2d 695 (Ala. Sup. Ct. 1996); Old Stone Mortgage \& Realty Trust v. New Georgia Plumbing Inc., 236 S.E.2d 592 at 594 (Ga. Sup. Ct. 1977). See also Gilmore, supra note 2 at 1021.

See Grise v. White, 247 N.E.2d 385 (Mass. Sup. Jud. Ct. 1969); ITT Diversified Credit Corp. v. First City Capital Corp. 737 S.W.2d 803 (Tex. Sup. Ct. 1987) . 
effect of the subordination agreement is that SP3 is subrogated to SP1's rights, and SP2's recovery is unaffected.

The Newfoundland and Labrador Court of Appeal in Re Hickman Equipment (1985) Ltd. ${ }^{39}$ the Alberta Court of Queen's Bench in Dynex, ${ }^{40}$ and the Ontario Superior Court of Justice in Re C.I.F. Furniture Ltd., ${ }^{41}$ have dealt with circular priority systems that arise in connection with a subordination agreement. In all instances, the court adopted the partial subordination or subrogation approach. It seems likely that a similar view will be adopted in the other Canadian common law jurisdictions that have not yet dealt with this question.

It should be emphasized that the nature and extent of the contractual subordination depends upon the precise wording that is used in the subordination agreement. ${ }^{42}$ It is therefore possible to create a step aside subordination agreement by using appropriate contractual language. Subordination agreements that merely refer to a subordination or postponement of a claim to another party will not result in a complete subordination. However, a subordination agreement under which a secured party agrees not to assert a claim until the claim of another is satisfied might well be interpreted to create a step aside agreement that leads to the complete subordination of the secured party's claim.

\section{B. BUYERS}

Priority competitions that involve buyers do not produce true circular priority systems. There is a fundamental difference between a priority competition among secured parties and one in which a buyer acquires an interest in the collateral. In Case 2, described above, B buys the collateral and thereby acquires an absolute interest in the goods free of SP1's security interest. B does not, however, take free of SP2's security interest. SP1's security interest in the goods has been cut off. It is no longer a case of ranking the claims of competing security interests. Rather, one of the competing claims has ceased to exist. There is no longer a circular priority problem, because SP1 has fallen out of the picture. In essence, B acquires good title against SP1, and SP2 can shelter behind B's good title. ${ }^{43}$ The resolution of this apparent circular priority problem is simple. B acquires title to the collateral, but SP2 retains its security interest in it since its security interest has not been cut off.

Several of the rules that govern competitions between secured parties and buyers use terminology that reinforces this point. For example, many of the buyer protection rules provide that a buyer who successfully invokes a buyer protection rule "takes free" from any security interest. ${ }^{44}$ Not all of the applicable buyer protection rules adopt this formulation. For example, in some jurisdictions the PPSA provides that an unperfected security interest is subordinate to a transferee for value without knowledge. ${ }^{45}$ In other jurisdictions, the PPSA provides that an unperfected security interest is ineffective against such a transferee. ${ }^{46}$ The

2006 NLCA 45, 259 Nfld. \& P.E.I.R. 49.

Bank of Montreal v. Dynex Petroleum Ltd. (1997), 202 A.R. 331 (Q.B.) [Dynex].

2010 ONSC 505, [2010] O.J. No. 240 (QL).

See Roy Goode, Commercial Law, 2d ed. (London: Butterworths, 1995) at 664-66.

For a discussion of the concept of sheltering, see ibid. at 60 .

APPSA, supra note 10, ss. 30(2), (3), (5), (7); OPPSA, supra note 10, ss. 28(1), (5).

APPSA, ibid., s. 20(b).

OPPSA, supra note 10 , s. 20(1)(b). 
outcome should not depend on the precise formulation that is used in the statute. The key point is that the effect of the rule is that the buyer obtains the seller's entire interest in the collateral free of the pre-existing security interest.

In some cases, the application of exactly the same PPSA priority rule will produce different outcomes. Consider the case that involves a negotiable document of title or instrument. Both SP1 and SP2 register. A subsequent party acquires possession of the collateral for value and with knowledge of SP2's security interest, but without knowledge of SP1's security interest. If the subsequent party is a buyer, SP1's security interest will be lost. Although the relevant PPSA priority rule provides that the holder or purchaser of the document of title or instrument has priority over a security interest that is perfected by registration, ${ }^{47}$ the fact that a buyer acquired it means that SP1's security interests can no longer be asserted against the collateral. The buyer acquires an absolute interest in the asset free of the pre-existing security interest. A circular priority system does not arise in this situation. However, a true circular priority system will arise if the holder or purchaser does not acquire the absolute interest in the collateral, but merely obtains a security interest in it. This does not have the effect of cutting off a security interest. The three security interests can all be asserted against the collateral, and it is merely a matter of ranking their priority. It is necessary in this instance to find some method of breaking the circularity that gives SP1 priority over SP2, SP2 priority over SP3, and SP3 priority over SP1.

\section{TRUSTEES IN BANKRUPTCY}

A similar analysis to that employed in respect of buyers is employed where one of the competing parties is a trustee in bankruptcy. The competition can arise where a secondranking secured party has a security interest that is effective against a trustee in bankruptcy, but the first-ranking secured party does not. This type of circular priority problem can arise in a variant of the scenario described in Case 6, above, involving a lapse or discharge of a registration. SP1 registers first, and SP2 registers second. SP1's registration then lapses or is discharged, and the debtor goes bankrupt before SP1 is able to re-register its security interest. SP1 has priority over SP2; SP2 has priority over the trustee; and the trustee has priority over SP1.

SP1's failure to amend its financing statement means that its security interest is ineffective against the trustee. This is not simply a matter of having a lower-ranking claim. The debtor's assets vest in the trustee, and SP1 is unable to assert its security interest as against the trustee. ${ }^{48}$ SP1's only recourse is to prove a claim as an ordinary unsecured creditor in the bankruptcy. In this respect, the situation is closely analogous to the situation of the buyer. SP1's security interest is lost. The circularity is broken since only one of the secured parties can assert a secured claim against the trustee. Priority therefore is given to SP2, and any surplus is to be turned over to the trustee.

$47 \quad$ APPSA, supra note 10, s. 31(4)-(5); OPPSA, ibid., s. 28(4).

$48 \quad$ Frankel v. Canadian Imperial Bank of Commerce (1997), 47 C.B.R. (3d) 244 at paras. $41-42$ (Ont. Gen. Div.). 
This analysis can also be applied in a variant of Case 7, involving a change of name or transfer of collateral. ${ }^{49} \mathrm{SP} 1$ registers first, followed by SP2. There is a change of debtor name or transfer. SP2 amends its registration in a timely manner after learning of the facts, but SP1 does not. The debtor goes into bankruptcy before SP1 amends its registration. Here, SP1 has priority over SP2; SP2 has priority over the trustee; and the trustee has priority over SP1. ${ }^{50}$ Only SP2's security interest is effective against the trustee. Priority is given to SP2, and any surplus must be turned over to the trustee. A similar circularity does not arise in Ontario, since SP1's failure to register a financing change statement results in a loss of perfection, so that SP1 is also subordinate to SP2. ${ }^{51}$

The analysis also applies in a variant of the scenario described in Case 4, involving fixtures. $\mathrm{M}$ is granted a real property mortgage in the debtor's land. ${ }^{52} \mathrm{SP}$ takes a security interest in goods. The goods are affixed to the land. SP fails to file a financing statement in the personal property registry. The debtor then goes bankrupt. SP has priority over M since the failure to file a fixtures notice does not affect its priority over a pre-existing real property interest. $\mathrm{M}$ has priority over the trustee because the goods have become part of the land and real property mortgages, whether registered or unregistered, are effective against a trustee in bankruptcy..$^{53}$ The trustee has priority over SP, since SP's failure to register renders its security interest ineffective against the trustee. This apparent circularity can be broken once it is recognized that SP's failure to register in the personal property registry results in a loss of its security interest in the goods. The trustee acquires the asset free of SP's security interest and the only priority competition is between the trustee and the mortgagee. The mortgagee therefore has first priority, and any surplus must be turned over to the trustee.

Master Funduk applied this mode of analysis in resolving a circular priority problem in the pre-PPSA case of Continental Bank of Canada v. Thorne Riddel Inc. ${ }^{54}$ The competition was between a conditional sales agreement, a subsequent chattel mortgage, and the trustee in bankruptcy of the debtor. Neither the chattel mortgage nor the conditional sales agreement had been properly registered. The chattel mortgage legislation provided that an unregistered chattel mortgage was void against creditors. However, the conditional sales legislation did not designate the trustee as one of the persons within the protected class of persons who could avoid an unregistered conditional sales agreement. The failure to register the conditional sales agreement resulted in its loss of priority against the chattel mortgage. As a consequence, the conditional sales agreement was subordinate to the chattel mortgage, the

49

The analysis also applies to a variant of Case 10: Statutory Deemed Trusts. The Crown has a statutory deemed trust that is subordinate to an unperfected secured instalment purchase agreement or lease covered by the PPSA. The debtor or lessee goes bankrupt, and the trustee in bankruptcy claims the goods. The secured party's failure to perfect results in a loss of its security interest, and the trustee acquires an interest in the goods subject only to the Crown's statutory deemed trust. See supra note 32. Re Stevens (1993), 23 C.B.R. (3d) 46 (Alta. Q.B.); Re Orion Truck Centre Ltd., 2003 BCSC 1167, 47 C.B.R. (4th) 99.

OPPSA, supra note 10 , ss. 48(1)-(3).

This analysis also applies in respect of an apparent circularity involving accessions. This occurs when SP1 takes and perfects a security interest in the dominant goods, SP2 takes a security interest in the accession goods but fails to perfect it, and the debtor subsequently goes bankrupt. SP2's failure to perfect results in a loss of its security interest, and the trustee acquires an interest in the whole subject only to SP1's security interest.

53 Re Canadian Engineering \& Contracting Co. (1994), 28 C.B.R. (3d) 136 (Ont. Ct. J. (Gen. Div.)); CitiFinancial Canada East Corp. v. Hurley (Trustee of), 2006 NBQB 133, 20 C.B.R. (5th) 74; see also Roderick J. Wood, Bankruptcy and Insolvency Law (Toronto: Irwin Law, 2009) at 123-25. (1982), 41 A.R. 541 (Q.B.). 
chattel mortgage was void as against the trustee, but the conditional sales agreement was valid as against the trustee. Priority was given to the conditional seller sales agreement on the ground that its rights were effective against the trustee, whereas the rights of the chattel mortgagee were not. The conditional seller therefore was given priority, with any surplus turned over to the trustee.

This also appears to be the approach adopted by the Court in Concentra Financial Services Association v. Kille. ${ }^{55}$ A priority competition arose between an unregistered lease and a security interest in three buses held as equipment. The debtor was bankrupt. Because the lease fell within the scope of the Saskatchewan PPSA, the interest of the lessor was ineffective against the trustee in bankruptcy due to its lack of perfection. The lender's security interest was effective against the trustee because it was perfected by registration. However, the lender did not register by serial number. Registration of serial numbers is required in order to perfect a security interest in a competition between two secured parties. ${ }^{56}$ Therefore, neither party had a valid registration for the purposes of applying the residual priority rule that governs competitions between secured parties. Ordinarily, a competition between two unperfected security interests would be decided according to their time of attachment. ${ }^{57}$ The Court found it unnecessary to analyze the priorities between the two secured parties, and awarded priority to the lender. This outcome is consistent with the view that the lessor's interest was lost upon the bankruptcy, and that only the lender had an interest that could be asserted against the trustee.

The mere fact that a trustee in bankruptcy is one of the competing claimants is not sufficient to invoke the principle under discussion. The principle only comes into play when a junior security interest is effective against a trustee, but a senior security interest is not. One must be careful to distinguish between this type of situation, and one that involves a subordination agreement. In Dynex, ${ }^{58}$ a secured creditor had subordinated its claim to an unsecured creditor. The debtor then went into bankruptcy. Here, the senior creditor's claim was effective against the trustee. The competition was resolved simply by giving effect to the subordination agreement between the secured creditor and the unsecured creditor. The secured creditor was entitled to priority over the trustee, but was bound to turn over any funds received from the disposition of the collateral up to the value of the unsecured creditor's claim.

There is one further matter that must be considered. A secured creditor is permitted to surrender its security to a trustee. ${ }^{59}$ If the secured creditor surrenders its security, the trustee in bankruptcy obtains the same right as the secured creditor and may assert the security against the property for the benefit of all the creditors. ${ }^{60}$ A trustee may argue that a surrender of a secured creditor's ineffective security interest permits the trustee to assert it as against

\footnotetext{
2008 SKQB 42, 43 C.B.R. (5th) 245.

APPSA, supra note 10, s. 35(4). The OPPSA, supra note 10, does not require serial number registration of goods held as equipment.

APPSA, ibid., s. 35(1)(c); OPPSA, ibid., s. 30(1).

Supra note 40 .

This must be accomplished through an irrevocable, unconditional, and unequivocal act of surrender. Merely valuing the claim at zero or proving as an unsecured creditor is not enough: see Andrew $v$. FarmStart (1988), 71 C.B.R. (N.S.) 124 (Sask. C.A.); Re Hollingshead, 1999 ABQB 355, 245 A.R. 85. Cracknall v. Janson (1877), 6 Ch. D. 735.
} 
the other claimant thereby giving the trustee the higher-ranking claim. This argument should be rejected. If the security is ineffective against the trustee, this means that the collateral vests in the trustee free of the security. As the creditor no longer has a proprietary right in the asset, it no longer has a security to surrender to the trustee. ${ }^{61}$

\section{The Resolution of True Circular Priority Systems}

Once apparent circular priority systems are screened out of the inventory, those that remain can be classified as true circular priority systems. The difficulty with true circular priority systems is not that there is no means to break the circularity. Rather, the difficulty is that there are many different ways that one might do so, but very little agreement about which is the best approach. ${ }^{62}$ The major approaches are discussed below, but it should be kept in mind that often there are a number of subvariants within an identified approach. Furthermore, as some of these solutions - such as fault-based approaches - are not applicable to all circular priority systems, there are also many different combinations of approaches that might be deployed.

\section{A. The Subrogation Approach}

The subrogation approach provides a workable solution to break the apparent circularity that arises in relation to subordination agreements. It is therefore not surprising that some courts try to use it to resolve other kinds of circular priority problems. When a subordination agreement is involved, the priority of the claims is ranked without regard to the subordination agreement. The party who has the benefit of the subordination agreement is then subrogated to the rights of the subordinating creditor. The junior creditor is subrogated to the rights of the senior creditor, since this is what the parties agreed to.

In a true circular priority system, the subrogation approach by itself provides no sensible method of assigning the initial priority ranking. There is no logical basis for assigning the role of the subrogator or the subrogatee to any particular claimant. ${ }^{63}$ This is illustrated in Case 10, above, involving a statutory deemed trust. Suppose that each claimant is owed $\$ 100$ and the value of the collateral is $\$ 250$. One might initially rank the parties as (1) Crown (C); (2) SP1; (3) SP2. SP2 would then be subrogated to C's interest up to the amount of SP2's claim. SP1 and SP2 would both recover in full, and C would recover only $\$ 50 .{ }^{64}$

61 This should be contrasted with the position under the United States Bankruptcy Code, 11 U.S.C, § 551 (1998). This section provides that any transfer that is avoided is preserved for the benefit of the bankrupt estate. Thus, if a security interest of a senior creditor is void against the trustee, the trustee may assert the priority of the senior creditor against the junior creditor and thereby obtain priority over both: see John C. McCoid II, "Preservation of Avoided Transfers and Liens” (1991) 77 Va. L. Rev. 1091. The provision is regarded as a statutory solution to a circular priority system.

62 A good summary of the various approaches that were developed in the United States is provided in Carville D. Benson, Jr., "Circuity of Lien — A Problem in Priorities” (1935) 19 Minn. L. Rev. 139 at 141-46.

63 See Michael Gillooly, "Priorities and the Problem of Circularity” in Michael Gillooly, ed., Securities Over Personalty (Sydney: Federation Press, 1994) 88 at 108; Burn, supra note 5 at 724.

64 In this example, $C$ would do better with any initial assignment of priority other than first. However, this will not always be the case. It all depends on the size of the respective claims. If C's claim is large and SP2's claim is small, C does relatively well. But if SP2's claim is equal or larger than C's, C will receive nothing until both SP1 and SP2 are fully paid: see Gilmore, supra note 2 at 1043. 
The problem with the subrogation approach is that it provides no guidance on how the initial ranking of priority is to chosen. Why was $\mathrm{C}$ chosen to head the list, and why was $\mathrm{C}$ assumed to subrogate its claim to SP2? With equal logic one could assign an initial ranking of (1) SP1; (2) SP2; (3) C, and subrogate C to SP1's claim. The subrogation approach alone therefore provides no means of breaking the impasse. To be useful it must be combined with some other principle that explains how and why the initial ranking is determined.

\section{B. The Fault Approach}

Where a fault-based circular priority problem arises, a court may choose to resolve it by throwing the loss on the party who failed to take the required steps to protect its interests. This approach is based on the theory that as between an innocent party and one at fault, the innocent party should be preferred. The approach is not capable of generating solutions where a non-fault-based circular priority problem is involved, and therefore this approach does not provide a solution to all problems.

One approach is to relegate the party at fault to the end of the queue by giving that party the lowest-ranking priority. They created the problem, so let them come last. Some courts in the United States have adopted this approach, sometimes referred to as the "New Jersey" rule. ${ }^{65}$ Consider its operation in relation to Case 3 , above, in which the inventory financer (PMSP) gave a purchase-money security interest notice to SP1 but not to SP2. The rule produces a ranking of (1) SP1; (2) SP2; (3) PMSP. This would give SP1 priority over PMSP despite the fact that SP1 was notified of PMSP's intention to take a purchase-money security interest. The approach has been criticized as being overly punitive to the party at fault, and overly generous to parties who were in no way prejudiced by the other party's failure to take the protective step. ${ }^{66}$

Courts that adopt a fault-based response to the resolution of a circular priority problem are more likely to combine it with a subrogation approach. ${ }^{67}$ The party who failed to take the protective step is assigned the first position. The party who is entitled to priority over the first ranking claimant by virtue of the failure to take the protective step is subrogated to the rights of that claimant. In the above example, the initial ranking is (1) PMSP; (2) SP1; (3) SP2. SP2 would then be subrogated to the extent of PMSP's claim. SP2 will fully recover if its claim is smaller than that of PMSP. If larger, it will be able to claim first priority only up to the amount of PMSP's claim.

A fault-based approach when combined with a subrogation approach gives a windfall to SP2. SP2 had registered after SP1 and could not reasonably have expected to recover anything until SP1 had been paid in full. And yet SP2 is the first to recover. Those who are unsettled by the prospect of undeserved windfalls may be more inclined to pursue a solution that looks to the reasonable expectations of the parties. 


\section{THE REASONABLE EXPECTATIONS APPROACH}

Instead of focusing upon fault, an alternative approach is to attempt to give effect to the reasonable or legitimate expectations of the parties. In fact, several different subvarieties of this approach have been proposed. The starting point is the dissenting judgment of Judge Dixon in the New Jersey case of Hoag, ${ }^{68}$ in which a formula - commonly referred to as the "Dixon formula" - was developed. Its operation is illustrated in the following scenario. Assume that A has priority over B; B has priority over C; and C has priority over $\mathrm{A}$. B and $\mathrm{C}$ are considered to be junior claimants and $\mathrm{A}$ is considered to be a residual claimant. The Dixon formula is designed to produce an outcome that gives effect to the reasonable expectations of the junior claimants. Each junior claimant has no reasonable expectation of recovering anything if the amount of the fund to be distributed is less than the amount needed to satisfy the claim of the higher-ranking party. Therefore, a distribution is made to a junior creditor only to the extent that the fund exceeds this amount. This is carried out through the application of the following set of rules: ${ }^{69}$

1. Pay C the amount of the fund less B's claim.

2. Pay B the amount of the fund less A's claim.

3. Pay A the remainder.

One curious feature of this approach is that the amount payable to A will often decrease as the fund grows in size. This is illustrated in the following example. Suppose that A, B, and $\mathrm{C}$ are each owed $\$ 100$. Table $\mathrm{A}$, below, sets out the payout structure as the size of the fund increases. When the fund is small, A will take it all. But as the fund grows in size, A's share will diminish and at one point will be reduced to zero.

TABLE A

\section{PAYOUT UNDER THE DiXon Formula}

\begin{tabular}{|l|l|l|l|}
\hline Amount of Fund & Payout to A & Payout to B & Payout to C \\
\hline$\$ 100$ & $\$ 100$ & $\$ 0$ & $\$ 0$ \\
\hline$\$ 130$ & $\$ 70$ & $\$ 30$ & $\$ 30$ \\
\hline$\$ 150$ & $\$ 50$ & $\$ 50$ & $\$ 50$ \\
\hline$\$ 170$ & $\$ 30$ & $\$ 70$ & $\$ 70$ \\
\hline$\$ 200$ & $\$ 0$ & $\$ 100$ & $\$ 100$ \\
\hline$\$ 250$ & $\$ 50$ & $\$ 100$ & $\$ 100$ \\
\hline
\end{tabular}

A owed \$100; B owed \$100; C owed \$100.

Ibid.

A.K. Kocourek, “A First-Rate Legal Puzzle: A Problem in Priorities” (1935) 29 Ill. L. Rev. 952 at 955 proposes a different formula that produces the same outcome as the Dixon formula, but which he claims is more explicative of the process: Deduct from the fund the amount of B's claim and apply the remainder (if any) to C's claim, and then after subtracting from A's claim the amount (if any) allocated to C, apply as follows: (1) A; (2) B; (3) A. Using a fund of $\$ 170$ from Table A by way of example, C would first be paid $\$ 70$ (the amount of the fund less B's claim). Next, A would receive A's claim less the amount paid to $C(\$ 30)$. The remainder would be paid to $B(\$ 70)$. 
Some commentators have expressed discomfort over the fact that the party who is responsible for the creation of the circular priority problem will often be entitled to take the lion's share when the size of the fund is small. ${ }^{70}$ Others have defended it on the basis that A's fault is irrelevant because the junior claimant had no reasonable expectation of recovering anything more. ${ }^{71}$ The junior claimant should have recognized that its claim was junior to a higher-ranking claim and that no distribution would be available if the amount of that senior claim exceeded the fund.

Nonetheless, the fact that A's recovery shrinks as the size of the fund increases creates a danger that the parties may attempt to artificially manipulate the sale price in order to enhance their recovery. B or C, or both, might attempt to artificially drive up the price, while A might attempt to reduce it. Their ability to do so would depend on the nature of the sale process and the person who has control over it. For example, if the property was sold by auction, $\mathrm{B}$ or $\mathrm{C}$ might submit inflated bids in order to squeeze out $\mathrm{A}$. If A controlled the process, A might attempt to sell by private sale at a reduced price in order to maximize A's recovery.

Some commentators have proposed variations to the Dixon formula in an attempt to correct these perceived deficiencies. Professor A.K. Kocourek proposed an exception to the Dixon formula that would prevent A from obtaining the whole fund.$^{72}$ Instead of giving it all to A the fund would be divided pro rata amongst the claimants. However, this creates an abrupt discontinuity when the claims are equal and the fund is less than or equal to the amount of any one of the claims. If the fund is less than one of the claims, it is divided pro rata. But if the fund slightly exceeds one of the claims, A will take most of the fund. This creates the possibility that A will attempt to overbid at a realization sale in order to diminish the recoveries of B and C. To curb this incentive he proposed a further adjustment: the fund should be distributed pro rata whenever the claims are equal and the fund does not exceed $4 / 3$ of one claim. ${ }^{73}$ Other commentators have proposed that A receive a fixed share of the fund that is independent of the size of the fund. ${ }^{74}$ This is designed to eliminate an undesirable characteristic of the Dixon rule — the tendency of A's recovery to diminish as the size of the fund increases.

Another difficulty with the Dixon formula is that no explanation is given as to which of the three claimants is to occupy A's position — that of the residual claimant. In Hoag, ${ }^{75}$ the holder of a first unregistered mortgage was placed in the position of $\mathrm{A}$, while a second

See Gilmore, supra note 2 at 1026. See also D. Kent Meyers, "Mortgages: Circular Priority,” Note, (1964) 17 Okla. L. Rev. 223 at 226.

71 W.A. Lee, “An Insoluble Problem of Mortgagees’ Priorities” (1968) 32 Conv. (N.S.) 325 at 336-37.

72 Kocourek, supra note 69 at 956-57. The exception would apply whenever the claims of A and B, respectively, are greater or equal to the fund.

73 Ibid. at 957-58; Gilmore, supra note 2 at 1028, observes that under this formula the fund is shared pro rata up until the point that $\mathrm{A}$ could no longer profit by artificially inflating the price.

74 "Circuity of Liens: A Proposed Solution,” Editorial Comment, (1938) 38 Colum. L. Rev. 1267 at 127576; Alan L. Tyree, "Circular Priorities in Secured Transactions” (1980) 87 The American Mathematical Monthly 186 at 193, proposes an alternative solution, more pleasing to mathematicians, that would eliminate the problem of a payout that decreases as the size of the fund increases. The mathematical formula is guaranteed to strike terror in the heart of any non-mathematician, and the author concludes that "[i]t is a sad truth that mathematics, so successful in the other social sciences, has had a minimal impact on legal thought." 
mortgagee who knew of the unregistered mortgage and a judgment lien claimant were treated as junior claimants. Some take the view that the party who would have had the top-ranking priority, but for a failure to take a protective step, should occupy this position. ${ }^{76}$ It is not entirely clear why this should be the case. ${ }^{77}$ It takes account of the reasonable expectations of the junior claimants - B and $\mathrm{C}$ - but it ignores the reasonable expectations of the residual claimant - A. The residual claimant does not expect recovery unless the fund exceeds the amount needed to pay out C. Moreover, the formula will not work when the priority competition arises because of conflicting priority rules rather than through a failure of a claimant to take a protective step. In this instance, some other rule must be employed to break the circularity, or else some further theory must be developed in order to explain which of the parties should be treated as the residual claimant.

Professor Carville Benson took a different view of the matter. He observed that there is no reason why A should be treated as a residual claimant. In a circular priority problem, each claimant is in the position of a junior claimant as there will be a claim that is senior to it. Therefore it is more appropriate to treat each claimant as if it were a junior claimant when determining the reasonable expectations of the claimants. ${ }^{78}$ He therefore proposed a distribution based on the principle that each claimant is entitled to have applied to the payment of its claim the portion of the fund that remains after the higher-ranking claim is satisfied. How this is accomplished will depend upon the size of the fund. Four classes of cases arise: ${ }^{79}$

Class 1: It may be that none of the claimants will have a reasonable expectation of recovery where the fund is small.

Class 2: The fund may be more than sufficient to pay the reasonable expectation of the claimants.

Class 3: The fund may be just sufficient to pay the reasonable expectation of the claimants.

Class 4: The fund may be insufficient to pay the reasonable expectation of the claimants.

This is illustrated in Table B, below. Assume that A is owed \$200, and B and C are each owed $\$ 100$. 
TABLE B

EXPECTATIONS OF THE PARTIEs UNDER THE BENSON FoRMUla

\begin{tabular}{|l|l|l|l|}
\hline Amount of Fund & Expectation of A & Expectation of B & Expectation of C \\
\hline$\$ 90$ & $\$ 0$ & $\$ 0$ & $\$ 0$ \\
\hline$\$ 140$ & $\$ 40$ & $\$ 0$ & $\$ 40$ \\
\hline$\$ 200$ & $\$ 100$ & $\$ 0$ & $\$ 100$ \\
\hline$\$ 260$ & $\$ 160$ & $\$ 60$ & $\$ 100$ \\
\hline
\end{tabular}

A owed \$200; B owed \$100; C owed \$100.

When the fund amounts to $\$ 90$, none of the claimants has a reasonable expectation of recovery, since there is no surplus after the senior claimant is paid. This conforms to Class 1. In this instance, the fund is divided equally among the claimants, and each would receive $\$ 30$. When the fund amounts to $\$ 140$, it is more than sufficient to pay the reasonable expectation of the claimants. This conforms to Class 2. Note that B does not have any reasonable expectation of recovery. A's claim is larger than B's claim. B therefore does not expect to recover anything until the fund exceeds $\$ 200$, while A and C reasonably expect to participate as soon as the fund exceeds $\$ 100$. Each claimant would receive their reasonable expectation, and the balance (\$60) would be divided evenly among all claimants. A and B each receive $\$ 60$, and $B$ receives $\$ 20$. When the fund amounts to $\$ 200$, it just sufficient to pay the reasonable expectation. This conforms to Class 3. A and C are each paid their reasonable expectation of $\$ 100$. When the fund amounts to $\$ 260$, it is insufficient to pay the reasonable expectation of the claimants. This conforms to Class 4, above. Here, the claimants receive the amount determined in Class 3 , and share equally in respect of the excess of the fund (\$60). Since C's claim has been paid in full, C does not participate in the excess. It is therefore divided equally between $\mathrm{A}$ and $\mathrm{B}$. The resulting payoff structure is set out in the Table C, below. Like the unmodified Dixon formula, it can produce a result where a claimant's share decreases as the size of the fund increases.

TABLE C

PAyOUT UNDER THE BENSON Formula

\begin{tabular}{|l|l|l|l|}
\hline Amount of Fund & Payment to A & Payment to B & Payment to C \\
\hline$\$ 90$ & $\$ 30$ & $\$ 30$ & $\$ 30$ \\
\hline$\$ 140$ & $\$ 60$ & $\$ 20$ & $\$ 60$ \\
\hline$\$ 200$ & $\$ 100$ & $\$ 0$ & $\$ 100$ \\
\hline$\$ 260$ & $\$ 130$ & $\$ 30$ & $\$ 100$ \\
\hline
\end{tabular}

A owed \$200; B owed \$100; C owed \$100.

\section{HYBRID APPROACHES}

A division can be drawn between circular priority problems that arise when a party fails to take some protective step that results in the subordination of its claim, and problems that do not involve this feature. A fault-based problem might occur through failure by a secured party to give a purchase-money security interest notice or a fixtures notice, failure to renew 
a financing statement, or failure to file a financing change statement after learning of a change of name or transfer of collateral. Other circular priority problems do not arise because of a failure of a party to take a protective step. Rather, they come about because of conflicting or unharmonized priority rules. Circular priority problems involving statutory deemed trusts and Bank Act security interests fall within this category.

Some of the approaches discussed above, most notably the Benson formula, are universal in that they apply to both types of problems. Other approaches purport to cover only one of the two categories - usually the fault-based circular priority problem. In such cases, there will be a need for some different approach to be used in respect of the other type of problem.

A note published in the Columbia Law Review offers a hybrid approach. ${ }^{80}$ A modified version of the Dixon formula is used in cases where a party fails to take a protective step. In respect of a non-fault-based circular priority problem (which is referred to as a true circuity), the authors propose an approach that recognizes the legitimate expectations of the parties and that also avoids a payout structure in which a claimant's share diminishes as the size of the fund increases. ${ }^{81}$ It is based on the idea that the claimant whose claim ranks immediately behind the smallest claim expects to be paid first.

Assume that A is owed \$100, B is owed \$200, and C is owed \$300. B expects to recover when the fund exceeds $\$ 100$. C expects to recover when the fund exceeds $\$ 200$. A expects to recover only when the fund exceeds $\$ 300$. The Columbia hybrid approach therefore gives $\mathrm{B}$ the amount that $\mathrm{B}$ would receive immediately before C's expectation of recovery is activated. B expects to recover $\$ 100$ when the amount of the fund is $\$ 200$. Therefore B receives the whole fund until it exceeds $\$ 100 .^{82}$ Thereafter, $\mathrm{B}$ and $\mathrm{C}$ receive equal increments until the fund reaches the point that A's expectation of recovery is activated. Accordingly, all amounts in excess of $\$ 100$ are distributed equally between $B$ and $C$ until the fund reaches $\$ 300$. At this point, A is also entitled to share. Since B's claim is fully paid off, any excess over $\$ 300$ is divided equally between $\mathrm{A}$ and $\mathrm{C}$. The resulting payout structure is set out in Table D, below.

81 The formal expression of the rule is as follows: “Ascertain what the junior lienholders' claims would be if the fund were of such size that the sum of the junior lienholders' claims were equal to what the fund is in fact. Pay these amounts to the respective claimants": ibid. at 1274. Using Table D, suppose that the fund available for distribution is $\$ 200$. We would deduce that if the fund were $\$ 250$, the sum of the junior lienholder's claims would equal $\$ 200$. B would receive a distribution of $\$ 150$ (the $\$ 250$ fund less A's claim of \$100) while C would receive a distribution of \$50 (the \$250 fund less B's claim of \$200). The sum of these two amounts is equal to the size of the actual fund $(\$ 200)$.

82 The entire fund is given to $\mathrm{B}$ when the fund is less than $\$ 100$ despite the fact that $\mathrm{B}$ did not reasonably expect to recover anything at this amount given A's senior claim. The reason why the whole amount is paid to B instead of being shared is that a major objective of this approach is to avoid a payout structure in which a share of a claimant declines as the fund grows larger. 
TABLE D

Payout Under the Columbia Formula (Non-Fault)

\begin{tabular}{|l|l|l|l|}
\hline Amount of Fund & Payout to A & Payout to B & Payout to C \\
\hline$\$ 100$ & $\$ 0$ & $\$ 100$ & $\$ 0$ \\
\hline$\$ 200$ & $\$ 0$ & $\$ 150$ & $\$ 50$ \\
\hline$\$ 300$ & $\$ 0$ & $\$ 200$ & $\$ 100$ \\
\hline$\$ 400$ & $\$ 50$ & $\$ 200$ & $\$ 150$ \\
\hline$\$ 500$ & $\$ 100$ & $\$ 200$ & $\$ 200$ \\
\hline$\$ 600$ & $\$ 100$ & $\$ 200$ & $\$ 300$ \\
\hline
\end{tabular}

A owed \$100; B owed \$200; C owed \$300.

\section{E. The Policy Approach}

Another approach to circular priority problems has been developed in cases from Australia $^{83}$ and the United Kingdom. ${ }^{84}$ These cases considered the effect of a statutory provision that gives certain preferential debts priority over the holder of a floating charge, and requires that the debt be paid out of any property subject to that charge. This rule does not apply in respect of a fixed charge. The controversy arises when the fixed charge is subordinate to the floating charge. This may occur because the holder of the fixed charge agreed to subordinate the interest to the holder of the floating charge, or it may arise because the subsequent holder of the fixed charge had knowledge of a restrictive provision by which the debtor agreed not to grant a fixed charge on the assets. ${ }^{85} \mathrm{~A}$ circular priority system arises because the floating charge has priority over the fixed charge, the fixed charge has priority over the preferential debts, and the preferential debts have priority over the floating charge.

The courts have broken the circularity by giving first priority to the preferential debts, second priority to the floating charge, and last priority to the fixed charge. Although the court might have applied a subrogation approach in respect of the cases in which the fixed charge holder subordinated its interest to the floating charge, they chose not to do so. ${ }^{86}$ Instead, the courts focused upon the particular wording of the statutory provision respecting preferential debts. The statute provided that preferential debts were to be paid out of any property subject to a floating charge. It had been long established that this does not include property that was subject to a fixed charge. ${ }^{87}$ The courts held that if the fixed charge was subordinate to the floating charge, then the floating charge could be said to encompass that asset as well. As a result, the preferential debts were entitled to be paid ahead of both charges.

Although the result ultimately depended on the proper interpretation of the statutory provision, both courts referred to the underlying policy of the preferential debts provision -

Waters v. Widdows, [1984] V.R. 503 (S.C.) [Waters].

In re Portbase Clothing Ltd. (1992), [1993] Ch. 388 [Portbase].

Ibid. at 401.

Professor Roy Goode has proposed using this approach when a floating charge holder claims priority over a fixed charge holder on the basis of a subordination agreement: see Roy Goode, Legal Problems of Credit and Security, 3d ed. (London: Sweet \& Maxwell, 2003) at 188-89; see also In re Woodroffes (Musical Instruments) Ltd., [1985] 3 W.L.R. 543 (Ch. D.). 
that preferential creditors such as employees should be given priority over a holder of a floating charge who allows the business of the company to carry on - and thought that it would be unconscionable to deprive the employees of this priority unless the legislation makes it very clear that this is to be the case.$^{88}$ This approach may be employed in other cases where it is possible to identify an overriding policy objective. Unfortunately, this task is often easier said than done. ${ }^{89}$ One might argue that Canadian legislation has clearly signalled an intention that the statutory deemed trust that is imposed on the employer's assets in respect of unremitted source deductions should have priority over other claimants, and that the Crown should not be denied this priority in the absence of very clear statutory language. On the other hand, it can be argued with equal justification that these kinds of statutory provisions deprive secured creditors of their pre-existing property rights and that the courts have always interpreted them strictly against the Crown. ${ }^{90}$

\section{F. THE CONVERSION APPROACH}

The Ontario Court of Appeal was confronted with a circular priority problem in G.M.S. Securities \& Appraisals Ltd. v. Rich-Wood Kitchens Ltd. ${ }^{91}$ A fixtures financer (Rich-Wood) took a security interest in cabinets that were later affixed to land. Rich-Wood failed to register a fixtures notice in the land registration system. Rich-Wood had priority over the holder of a first mortgage on the land (National Trust), since the mortgagee was not a subsequent mortgagee (except to the extent of a future advance in respect of which it was entitled to priority). The failure to register the fixtures notice resulted in a subordination of Rich-Wood's security interest to a holder of a second mortgage on the land (GMS). As a result, Rich-Wood had priority over National Trust, National Trust had priority over GMS, and GMS had priority over Rich-Wood. National Trust caused the land to be sold pursuant to its power of sale, and a priority competition arose in respect of the proceeds of sale.

The Ontario Court of Appeal did not apply a fault-based approach of the kind discussed above. This would have given GMS the benefit of Rich-Wood's priority. Instead, it took the view that National Trust, by selling the land, had converted Rich-Wood's interest in the cabinets. National Trust was therefore required to pay Rich-Wood the value of the cabinets. Because National Trust had paid out Rich-Wood, National Trust had the right to be subrogated to any security interest held by Rich-Wood. However, Rich-Wood's failure to register a fixtures notice meant that this security interest was of no value as against GMS.

There are a number of difficulties with this approach. First, it is impossible to apply before one of the parties has realized against the collateral. Suppose that National Trust had sought a determination of priorities before it caused the land to be sold. The approach could not

$88 \quad$ Waters, supra note 83 at 514; Portbase, supra note 84 at 400-407.

89 Some courts in the United States have attempted to apply the policy-based approach to break a circularity. In Re Quaker City Uniform Co., 238 F.2d 155 (3rd Cir. 1956), the Court held that the policy of favouring expenses of administration and wage claims in bankruptcy was by necessary implication presumed to demonstrate an intention that the circularity should be broken in favour of the wage claimants and the costs of administration. However, other courts have not been inclined to endorse this approach: see Jordan v. Hamlett, 312 F.2d 121 (5th Cir. 1963); see also "Circuities of Priorities and Liens under Section 67c(1) of the Bankruptcy Act,” Note, (1957) 66 Yale L.J. 784. 
generate an outcome since Rich-Wood's interest would not have been converted. Second, the party who was responsible for the creation of a circular priority problem (Rich-Wood) ends up with first priority. Third, the approach ultimately imposes the loss on the first party to take steps to realize against the collateral. Suppose that it was Rich-Wood that exercised its right to remove the fixture from the land. GMS could claim the value of the cabinet from Rich-Wood, since Rich-Wood would have taken property to which GMS had a better claim. In this case, the loss would ultimately be borne by Rich-Wood rather than by National Trust.

\section{G. The Residual Priority Rule Approach}

The PPSAs provide a residual priority rule that determines competitions between secured parties where no other priority rule is applicable. Where both security interests have been perfected, priority is given to the first to register. ${ }^{92}$ Some have argued that if the specialized PPSA priority rules do not resolve a circular priority competition, this residual priority rule should be used to determine priorities. ${ }^{93}$ This produces an outcome that is often similar to a fault-based approach that relegates the party at fault to the lowest ranking, though the rationale for doing so is different. For example, in Case 3, above, involving an inventory financer (PMSP) who gives a purchase-money security notice to SP1 but not to SP2, the order of priority would be (1) SP1; (2) SP2; (3) PMSP. In the case of a lapsed or discharged registration, the re-registering party (SP1) would have the latest registration with the result that priority would be (1) SP2; (2) SP3; (3) SP1. At best, this is a partial solution. Many of the circular priority systems involve parties who do not hold security interests that are governed by the PPSA. In these cases, the residual priority rule can have no application.

\section{H. The Pro Rata Approach}

With so many different solutions to circular priority problems, one might have thought that the courts would have embraced the relatively simple step of dividing the fund pro rata among the claimants. If the application of the priority rules do not produce a stable ranking, it is not unthinkable that a court might simply decide to let them share in the fund. This appears not to have attracted much support. Professor Michael Gillooly argues that this may be due to the traditional "winner take all” approach of the law, and the belief that secured creditors ought not to be treated equally but that the system of secured transactions law operates best if the claims of secured creditors fall into an established hierarchy or ranking. ${ }^{94}$ Cases from the United States similarly take the view that the proprietary nature of secured claims necessitates a ranking of the claims even if this may result in a complex and sophisticated distribution analysis. ${ }^{95}$ concludes that if the claims are of equal rank, the circularity should be resolved by permitting the claimants to share pro rata in the fund.

In re Darnell, 834 F.2d 1263 (6th Cir. 1987); In the Matter of: Cliff's Ridge Skiing Corp., 123 B.R. 753 (W.D. Mich. Bankr. 1991). 


\section{Assessing the Approaches}

The foregoing discussion demonstrates that the difficulty encountered by a judge who must resolve a circular priority system is not that the problem is insoluble. Rather, there is a plethora of approaches, but little guidance as to which should be chosen. One might take the view that a circularity can only be solved by cutting the Gordian knot, and the choice of where to cut is essentially an arbitrary one. Once a decision is made, certainty and predictability is created through the binding force of precedence. This attitude is unhelpful. A judge who is struggling to reach a solution will likely not appreciate the suggestion that an arbitrary choice should be made. The judge will not be inclined to decide the matter on a coin toss. ${ }^{96}$ Although difficult, the search for principle and rationality must be pursued.

Grant Gilmore described the proliferation of new approaches for breaking the circularity as an "admirable parlor game." ${ }^{, 7}$ One suspects that a search for new and elegant variations of the various approaches will do little to improve matters. What is most needed is some basis for choosing amongst them. We should seek to identify a set of criteria against which the various approaches can be tested. These criteria should be those that promote the general values and goals of commercial law. With this in mind, the following criteria have been chosen:
- $\quad$ Simplicity
- $\quad$ Predictability
- Universality
- $\quad$ Incentive Effect
- $\quad$ Congruence with Commercial Expectations

\section{A. Simplicity}

A simple rule is generally preferred over a complex rule. A complex rule creates greater opportunities for error, and makes risk assessment more difficult for the parties. The set of proposed solutions that fall under the reasonable expectations approach have a very high degree of complexity in their application. ${ }^{98}$ Although the Dixon formula is the easiest to apply, it produces outcomes that many commentators have considered unacceptable. Others have attempted to remedy these problems through the construction of more complicated formulas, but one wonders if the cure is not worse than the disease.

\section{B. Predictability}

A fundamental value pursued in commercial law is the quest for certainty and predictability of outcomes. Some of the approaches fail badly on this criterion. A subrogation

$96 \quad$ But see Maddox, supra note 4 at 892 where the Court states: "It seems to me that the question of priorities, according to any of these formulas would be a matter of chance, and which formula to follow, which one to take first, might as well be determined by the turn of a card or the throw of the dice or the selection of a number."

$97 \quad$ Supra note 2 at 1032.

$98 \quad$ Kocourek, supra note 69 at 953 states that "[m]asters, chancellors, and appellate judges would find themselves in an intellectual bellum internecinum" in attempting to apply the Benson formula. Kocourek's own formula, although somewhat less complex, is hardly a model of simplicity. 
approach alone is highly unpredictable because the outcome depends entirely upon the initial order of ranking of the parties. It is only capable of producing predictable outcomes if it is combined with some other theory or principle that determines the initial ranking. The conversion approach also fails this test, as it does not produce an outcome if none of the parties has enforced against the collateral. A policy-based approach is also difficult to generate predictable outcomes, since the merits of the competing legislative policies must be identified and resolved for every different circular priority system.

\section{UNIVERSALITY}

A universal approach is preferred over an approach that generates a solution to one or only a few of the circular priority problems. There are two reasons why this is the case. A nonuniversal approach leads to greater complexity, since a whole series of different approaches are needed to resolve the entire population of circular priority problems. Second, there is little guidance on how new circular priority problems based on new legislative rules should be resolved, as there will be controversy over which of the various approaches should be applied to it. Some of the approaches that have been discussed are very limited in their application. The residual priority rule approach cannot be applied in a majority of the circular priority problems that have been identified. The policy-based approach is similarly limited to a few instances in which a clear overarching policy can be discerned.

\section{INCENTIVE EFFECT}

Some of the approaches give rise to perverse incentives on the part of the parties. The conversion approach provides a good example of this phenomenon. Under this approach, the loss is ultimately borne by the party who takes the first step to enforce its claim. That party is required to pay out the party who ranks over its claim, and is rewarded for its efforts with a right to be subrogated to a valueless claim. This produces a strong incentive not to take any action to enforce a claim since it will result in the subordination of that party's security interest. This is precisely the wrong incentive that is needed. It produces a standoff in which no party is willing to take action in situations when timely enforcement action by the creditors is highly desirable.

The Dixon formula and the Benson formula may also produce undesirable incentives. Both of these produce a payout scheme in which the payout to the residual claimant declines as the funds increases. This gives the parties an incentive to manipulate the sale process to produce a return that gives it the most favourable payout. Although other approaches have attempted to modify the formula to produce a payout structure that does not diminish as the fund increases, this produces much greater complexity in the rule.

Fault-based approaches tend to produce correct incentives. Because the loss is borne by the party at fault who has created the circular priority, that party will have an incentive to take precautions to ensure that the protective step is taken in a correct and timely manner. 


\section{E. CONGRUENCE WITH COMMERCIAL EXPECTATIONS}

A rule that is congruent with the reasonable commercial expectations of the parties is preferred over one that generates counterintuitive outcomes. The reasonable expectations approaches are directly premised on a desire to respect the legitimate commercial expectations of the parties. Unfortunately, when one examines the payout structure that is generated it is difficult to believe that these are ones that would be even remotely anticipated by any reasonable commercial party. Gilmore commented that one "is left with the impression that he has just witnessed the passage of three camels named A, B and C through the needle's eye." 99 Although the Dixon formula is the easiest to apply, it does not provide a satisfactory explanation of why only the reasonable expectations of two of the three parties (the junior claimants) are worthy of consideration.

One can argue that a reasonable expectations approach is too narrow in its perspective. It looks only at one element of the problem: what would a party expect to recover knowing that its claim is junior to a higher-ranking claim? But there is another expectation that might be considered. Litigation and other costs have been forced upon an innocent party because of another party's failure to take appropriate precautions. The innocent party has a legitimate expectation that the loss should be borne by the party who was responsible for the creation of the problem.

\section{F. THE PREFERRED APPROACH}

The approach that best fits the criteria that have been identified is a modified subrogation approach. It is modified in the sense that the approach is augmented by a principled means of assigning the parties to their initial priority positions. Where a party is at fault, the party who is at fault is assigned the position of $\mathrm{A}$, and the party who has priority over A by virtue of that fault is assigned the position of $\mathrm{C}$. $\mathrm{C}$ is then subrogated to the claim of $\mathrm{A}$. B is no worse off under this rule. It is true that $\mathrm{C}$ may not have any legitimate expectation to recover anything given that B's claim outranked that of C. ${ }^{100}$ Given the failure of the reasonable expectation approach to provide a superior rule, this can be tolerated as an acceptable cost.

This rule will resolve most of the priority disputes that have been identified under the PPSA. However, there are some in which none of the parties have failed to take a protective step. When the circular priority is not based on the fault of a party, some other principle must be devised in order to assign the initial ranking. This type of priority competition most often arises where there is a competition with a PPSA security interest and an interest that is not governed by the PPSA. Here, one should assign the initial ranking based on the time of

$99 \quad$ Supra note 2 at 1031.

100 Michael P. Pearson, “Absolute versus Conditional Protection for Secured Parties: Problems of Lapsed Perfection under Article 9 of the Uniform Commercial Code” (1979) 17 Hous. L. Rev. 1 at 16 makes the following argument in favour of an extension of the subrogation approach: "While it may be inappropriate to speak in terms of the reasonable expectations of the parties in such a morass, this solution is roughly equitable because it preserves the approximate priority positions of the parties at the time they perfected their security interests. In so doing, it does not permit any one party to enjoy a windfall at the expense of the others"; see also Blake Elliot Rasmussen, "Texas Adopts the 'Subordination' Rule to Solve Circular Priority Disputes Involving Personal Property: ITT Diversified Credit Corp. v. First City Capital Corp., 737 S.W.2d 803 (Tex. 1987)” (1988) 19 Tex. Tech. L. Rev. 1511 at $1521-22$. 
creation of the interests. This is consistent with early English decisions that have applied a subrogation approach and assigned the initial priority ranking on a temporal basis. ${ }^{101}$ Where a title reservation device is used, the party who reserves title is regarded as the first in time, with the other interests ranked according to time of creation of their interests. ${ }^{102}$ If both arise simultaneously pursuant to after-acquired property clauses in their security agreements, priority is given to the first security agreement to be executed. ${ }^{103}$

The circular priority system that arises in connection with a $B A$ security provides a case in point. ${ }^{104}$ It arises because the federal and provincial priority rules are not properly coordinated. SP1 takes a security interest and registers first. BK takes a BA security and registers in the $B A$ registry, and SP2 then takes and registers a purchase-money security interest. The solution is to initially rank the interests according to the time of their creation. The ranking is therefore (1) SP1; (2) BK; (3) SP2. SP2 is then subrogated to the rights of SP1.

In some cases, it will be necessary to consider whether a fault-based or non-fault-based approach should be applied. For example, the circularity that arises in connection with a judgment enforcement creditor does not involve a failure to register or to take some other protective step. ${ }^{105}$ SP1 has priority over SP2, but SP1 is subordinate to the judgment enforcement creditor to the extent new advances made after learning of the enforcement measures of the judgment enforcement creditor. One might nevertheless argue that SP1 should be treated as a party at fault since it advanced new money despite having knowledge of an intervening judgment enforcement creditor. In any event, it makes no difference to the outcome in this case. SP1's interest was the first to arise, and therefore SP1 would be placed in the position of A even in the absence of fault.

The modified subrogation approach is relatively simple to apply and it produces predictable outcomes. It comes close to providing a universal rule. It applies to both faultbased and non-fault-based circular priority systems, with the only difference being the factor that is used to determine the identity of the party who is assigned the initial priority position. It does not produce a set of perverse incentives, but instead reinforces the incentive to take appropriate protective steps. Although it might be thought that one of the parties (C) receives a windfall gain, the reasonable expectation approaches do not seem to do any better and yet fail badly when tested against the other criteria. It also accords with the expectation that a loss should fall on the party at fault. Finally, it has the great advantage of being in accord with most of the U.S. decisions that have considered the matter following the modernization of personal property security law under Article 9 of the Uniform Commercial Code, and receiving the endorsement of Gilmore in his highly influential treatise. ${ }^{106}$ supra note 63 at 108-11.

$102 \quad$ Kawai, supra note 30; YMCF, supra note 30. 


\section{The Effect of Ex Post BARgaining}

Circular priority systems are inherently unstable. Even if the judiciary were able to reach a consensus on how to break the circularity, a victory would remain elusive. The certainty and predictability that one might expect from a definitive rule is undercut and threatened by the effect of post-default bargaining among the parties. This instability is intrinsic to the structure of a true circular priority system, and comes into play regardless of the particular approach that is adopted by the courts to break the circularity.

The problem is illustrated in the following simple example. A has priority over B, B has priority over C, and C has priority over A. Each has a claim for \$100, and there are assets valued at $\$ 100$ for distribution. Assume that the judiciary has agreed that a modified subrogation approach should be used to resolve the circular priority system. The outcome is that $C$ recovers $\$ 100$, while $A$ and $B$ recover nothing. But there is now the possibility of a value-enhancing bargain between A and B. Suppose that A agrees to waive or release its security interest in the collateral in return for a payment of $\$ 50$ from $B$. The voluntary action of the parties breaks the circular priority system. A is out of the picture, and the only remaining priority competition is between $\mathrm{B}$ and $\mathrm{C}$. $\mathrm{B}$ has priority over $\mathrm{C}$, and therefore has priority over the entire fund. B recovers the fund of $\$ 100$, but has paid $\$ 50$ to $A$. The end result is that both $\mathrm{A}$ and $\mathrm{B}$ recover $\$ 50$, while $\mathrm{C}$ recovers nothing.

Matters do not necessarily end here. $\mathrm{C}$ may counter with an offer to release its claim in return for a payment from A. For example, C may offer to release its claim for $\$ 40$. The net result would be that $A$ would receive $\$ 60$ and $C$ would receive $\$ 40$. This in turn would spur B to make an offer to $\mathrm{C}$ to release its claim at a payout that improves C's return. Ultimately, two of the parties will gang up against the third to freeze out that party. This choice may well depend on the nature of the relationship between the parties and the possibility of future dealings between them.

The problem does not disappear under a formula that results in a sharing among the creditors. For example, under the Benson formula, each creditor would receive the same amount in this particular scenario. Despite this, there is still an incentive for one of the parties to agree to release its claim in order to freeze out a party who is senior to it. For example, A may agree to release its claim in return for a payment of $\$ 50$ from $B$. The net result is that $\mathrm{A}$ and $\mathrm{B}$ each receive $\$ 50$, while $\mathrm{C}$ receives nothing.

Ex post bargaining resolves a circular priority system in the sense that the matter is never brought before the court, and therefore there is no need for the court to resolve a circular priority system. However, it is problematic in that it leads to unpredictable outcomes and wasted expenses in the post-default period, and to the inability to assess risk in the predefault period. ${ }^{107}$ 
One could argue that the priorities are crystallized at some point in time, and that it is not thereafter possible for the actions of the parties to alter this ranking. Courts in Canada have accepted the proposition that priorities crystallize at the point in time when a claimant enforces a security interest against the collateral. ${ }^{108} \mathrm{~A}$ court may decide to apply this theory and crystallize priorities in respect of a circular priority system at the time of enforcement. In the example above, $\mathrm{C}$ would be entitled to the whole fund and the other parties would get nothing. If any of the parties enforced against the collateral, the priority of the parties would crystallize and any release or waiver that is thereafter given by A would not affect C's claim.

It is by no means clear that an extension of the crystallization approach is warranted in this context. The idea that the priorities crystallize at the time of enforcement so as not to be affected by subsequent actions arose in cases that involved a lapse in registration after an enforcement step had been taken. In these cases, neither of the competing security interests were waived or released, and the only issue concerned the time when the priority rule should be applied. The concept has never been used to support a theory that a security interest will continue to exert an influence on the priorities of other parties even after its release. Suppose that SP1 is the senior ranking creditor and SP2 is the junior ranking creditor. SP2 has seized the collateral. Both have claims for \$100 and the collateral is worth only \$150. SP1 has priority over SP2, and SP2 will only be entitled to recover \$50. But SP1 later decides to release its security interest. It is highly doubtful that a court would apply a crystallization of priorities approach and limit SP2's claim to \$50 in this instance. For similar reasons, it may be argued that the approach should not be used when a secured party waives or releases a claim in connection with a circular priority problem.

Furthermore, the crystallization of priority theory does not eliminate the problem of altering the priority resolution through ex post bargaining. Even if one accepts the theory, the point at which the priority rights are fixed is the date when one of the parties enforces its security interest against the collateral. This theory would therefore be of no assistance in respect of any releases or waivers that were given before enforcement.

\section{Minimizing THE INCIDENCE OF CiRCUlaR PRIORITY SYSTEMS}

Given the inherent instability of a circular priority system, it is not realistic to think that all problems associated with them can be eliminated by the courts or by the design of the legislative priority rules. This does not mean that the task is hopeless. Courts can agree upon a simple and predictable rule for those cases where a circular priority problem is brought before the court for resolution, and legislators can design secured transactions law so as to reduce the instances where a circular priority system can arise.

Circular priority systems can be minimized by the avoidance of priority rules that depend on knowledge. The classic example is the priority rule that subordinates an unregistered interest (A) to subsequent parties who are without knowledge. A circular priority system arises whenever $\mathrm{B}$ has knowledge but $\mathrm{C}$ does not. Circular priority systems are also more 
likely to arise when the priority rule selectively confers priority to a subset of potential claimants when a secured party fails to properly take some required step such as registration or giving notice. This is illustrated in connection with a post-registration change in the debtor's name. In Ontario, this does not give rise to a potential circular priority system because the effect of a failure to amend a registration is the same regardless of whether the competing claimant acquired its interest before or after the change of name. In the other jurisdictions, a failure to amend does not result in a loss of perfection, but merely subordinates the security interest to certain classes of subsequent interest holders. This creates the conditions required for a circular priority system to arise.

This is not to say that the legislation should always strive to avoid circular priority systems. Sometimes it is appropriate to accept the risk of a circular priority system in order to achieve some other objective. ${ }^{109}$ In some instances, the architects of personal property security legislation have deliberately decided to make this trade-off. ${ }^{110}$ Even when this choice is made, it is often possible to minimize the incidence of circular priority problems. One method is to shorten the duration of the period within which circular priority systems can arise in order to reduce the frequency of their occurrence. This strategy can be seen in the approach taken to lapsed or discharged registrations in jurisdictions other than Ontario. A secured creditor who has a lapsed or discharged registration is given a 30-day period within which a special re-registration procedure can be utilized to get its registration back on the system. This greatly limits the occurrence of circular priority systems, as it is only during the 30-day period that a circular priority system can arise. There is a deliberate trade-off in the design of this type of rule. The possibility that a circular priority system will arise is kept to an acceptable level so that some other legislative objective can be realized.

Circular priority systems can be limited by harmonizing the priority rules of non-PPSA devices such as $B A$ security or statutory deemed trusts so that they are better integrated with the priority structure of the PPSA. This might involve the adoption of a priority rule that subordinates a deemed trust or $B A$ security to a purchase-money security interest taken by a lender. This would lead to better coordination between the federal and provincial priority rules and a reduction in the number of occasions in which circular priority competitions arise. In rare cases, the legislation may be drafted so as to include a priority rule that is specifically designed to resolve a potential circular priority system. ${ }^{111}$ This is very much the exception, and the usual attitude of the legislative drafters appears to be that the benefits of greater predictability is outweighed by the increased complexity and reduced comprehensibility of

R.C.C. Cuming, "Judicial Treatment of the Saskatchewan Personal Property Security Act” (1986) 51 Sask. L. Rev. 129 at 139-40 states that "[w]hile circular priority problems cannot always be avoided, there must be a strong public policy basis for adopting rules that carry with them a significant potential for creating circular priority problems."

110 The Law Reform Commission of Saskatchewan, in Proposals for a Saskatchewan Personal Property Security Act (Saskatoon: Law Reform Commission of Saskatchewan, 1977) at 64 recognized that a circular priority system might arise in connection with the re-registration of a lapsed or discharged registration, but was of the opinion that that "the possibility that a circular priority will develop is the lesser of the two evils."

111 See Land Title Act, R.S.B.C. 1996, c. 250, s. 203, which deals with a circular priority competition amongst (1) an uncrystallized floating charge registered in the personal property registry; (2) a crystallized floating charge registered in the land titles system; and (3) an encumbrance against land registered in the land titles system. For a discussion of the specialized statutes dealing with floating charges on land, see Law Reform Commission of British Columbia, Report on Floating Charges on Land (Vancouver: Law Reform Commission of British Columbia, 1989); Roderick J. Wood, "The Floating Charge on Land in the Western Provinces” (1992) 20 Can. Bus. L.J. 132. 
a statute that attempts to provide individualized solutions to every potential circular priority system.

Although judges are usually called upon to break circular priority problems that have already come into existence, they also have a limited ability to implement strategies for keeping circular priority problems in check. Some courts have indicated that, when interpreting legislation, they will be more inclined to adopt an interpretation that does not result in the creation of a circular priority problem. ${ }^{112}$ This type of approach can be applied in connection with the debate over the appropriate test for seriously misleading registration errors. Some cases that have dealt with registration errors have departed from an objective test that involves a hypothetical searching party and have embraced a subjective test that looks to the state of knowledge of the party that is challenging the registration. ${ }^{113} \mathrm{~A}$ subjective test is more likely to produce circular priority systems. SP1 registers, but the financing statement contains an error. SP2 knows of SP1's security interest, but SP3 does not. SP1 has priority over SP2, since SP1's registration was not invalid against SP2 due to SP2's knowledge. SP2 has priority over SP3, since SP2 has the earlier registration. SP3 has priority over SP1 because SP1's registration was invalid against SP3 due to the error. If the court adopts an objective test, SP1's registration will either be valid against both or invalid against both. In either event, a circular priority system does not arise. This is one of the reasons why some experts have argued against the subjective approach. ${ }^{114}$

\section{CONCLUSION}

Just as there is presently no cure for the common cold, so too is there no cure for circular priority problems. The best we can do is to take precautions to protect ourselves, and to follow a sound regimen when we do succumb. Once we understand the nature of the problem we can differentiate between true circular priority systems and those that merely have a superficial resemblance to such systems. The latter do not create difficulties, since the apparent circularity can easily be resolved. We can design secured transactions law so as to reduce the occasions when true circular priority problems arise. For those who nevertheless become enmeshed in a circular priority system, the adoption of a simple and predictable rule for breaking the circularity will at least reduce litigation costs. Unfortunately, judicial concurrence on a rule for breaking the circularity will not eliminate the problem. A circular priority system is highly unstable. By accepting a side payment in return for releasing or waiving its claim, a party can fundamentally alter the distribution that would otherwise ensue. Given the vast array of circular priority systems that are possible, one wonders whether this explains why we do not see these types of problems litigated more often. 